Обоснование. Проблема диагностики, лечения и профилактики жирового гепатоза (ЖГ) является одной из актуальных проблем современной медицины. В этой связи возникает потребность в создании надежных экспериментальных моделей ЖГ, которые были бы максимально приближены к патогенетическим закономерностям развития данного заболевания у человека.

Цель. Создание экспериментальной модели ЖГ и сравнение эффективности ее воспроизведения у крыс разного возраста.

Материалы и методы. Исследование проведено на крысах-самцах линии Wistar, возраст которых в начале эксперимента составлял 3 и 18 мес. Контрольные животные находились на стандартном рационе питания. Подопытные крысы в течение 12 нед содержались на рационе с избыточным содержанием жиров (45\%) и углеводов (31\%). Для морфологических исследований ЖГ отбирали образцы ткани печени, из которых изготавливали гистологические препараты по стандартной методике. Морфометрию на цифровых изображениях микропрепаратов осуществляли с помощью компьютерной программы IMAGE J. В ткани печени определяли концентрацию липидов, холестерина и триглицеридов, а в сыворотке крови определяли концентрацию аланинаминотрансферазы. Для оценки биофизических свойств печеночной ткани использовали метод мультичастотной биоимпедансометрии.

Результаты. О наличии ЖГ после влияния предложенного нами высококалорийного рациона свидетельствуют увеличенная масса печени, ее бледноватый оттенок и мягкая консистенция. Также выявлены морфометрические признаки ЖГ: гипертрофия гепатоцитов с одновременным снижением ядерно-цитоплазматического соотношения, накопление в цитоплазме многочисленных липидных включений, появление крупных липидных капель, которые замещали пустоты погибших гепатоцитов, снижение количества двуядерных гепатоцитов и ядрышек в ядрах, уменьшение относительной площади сети синусоидов. Наблюдали возрастание концентрации липидов, холестерина и триглицеридов в ткани печени подопытных крыс, а также активности аланинаминотрансферазы в сыворотке крови. Изменение показателей биоимпедансометрии печеночной ткани также свидетельствовало о развитии выраженной жировой дистрофии печени как у молодых (в большей степени), так и у зрелых крыс.

Заключение. Предложенная нами модель ЖГ на основе комбинированного (жироуглеводного) высококалорийного рациона у всех подопытных крыс приводит к развитию выраженных морфологических, биохимических и биофизических признаков данной патологии. Наиболее выраженные проявления ЖГ наблюдаются у молодых животных.

КЛЮЧЕВЫЕ СЛОВА: печень; жировой гепатоз; высококалорийный рачион.

\title{
FEATURES OF MODELING FATTY LIVER DISEASE IN RATS OF DIFFERENT AGES BASED ON A HIGH-CALORIE DIET
}

(c) Roman V. Yanko*, Elena G. Chaka, Anastasia S. Zinchenko, Sergey L. Safonov, Mikhail L. Levashov

Bogomoletz Institute of Physiology, Kiev, Ukraine

BACKGROUND: The problem of diagnosis, treatment and prevention of fat liver disease (FLD) is one of the actual problems of modern medicine. In this regard, the need for the creation of reliable experimental models of the FLD, which would be as close as possible to the pathogenetic patterns of the development of this disease in humans.

AIM: To create an experimental model of FLD and compare the efficiency of its reproduction in rats of different ages.

MATERIALS AND METHODS: The study was conducted on male Wistar rats, whose ages at the beginning of the experiment were 3 and 18 months. Control animals were fed a standard diet. The experimental rats were kept on a diet with excess fat (45\%) and carbohydrates (31\%) for 12 weeks. The liver tissue samples were taken for morphological studies of FLD. Histological preparations were made according to the standard technique. Morphometry on digital images of micropreparations was conducted using the computer program «IMAGE J». The concentration of lipids, cholesterol, and triglecerides in the liver tissue was determined, and the concentration of ALT in the blood serum was determined. To assess the biophysical properties of the liver tissue, the method of multifrequency bioimpedance measurement was used.

RESULTS: The transfer of animals to a high-calorie diet developed by us led to the development of FLD. This was evidenced by an increase of the liver mass, its pale shade and soft consistency. Morphometric signs of FLD were also revealed. Hypertrophy of hepatocytes was observed with a simultaneous decrease in the nuclear-cytoplasmic ratio; accumulation of numerous lipid inclusions in the cytoplasm and the appearance of large lipid droplets replacing the voids of dead hepatocytes. The number of binuclear hepatocytes and nucleolus in the nucleus, the relative area of the sinusoid network were decreased. An increase

*Автор, ответственный за переписку / Corresponding author. 
in the concentration of lipids, cholesterol and triglecerides in the liver tissue of experimental rats, as well as the activity of ALT in the blood serum, was observed. Changes in the bioimpedance measurements of the liver tissue also indicated the development of severe fatty degeneration of the liver in both young (to a greater extent) and old rats.

CONCLUSION: The model of FLD we have advanced based on a combined (fat-carbohydrate) high-calorie diet. It leads to the development of pronounced morphological, biochemical and biophysical signs of this pathology in all experimental rats. The most pronounced manifestations of FLD are observed in young animals.

KEYWORDS: liver; fatty liver disease; high-calorie diet.

\section{ОБОСНОВАНИЕ}

Жировой гепатоз (ЖГ) (неалкогольная жировая болезнь печени, стеатоз печени, жировая дистрофия печени) - самое распространенное хроническое заболевание печени, которое обнаруживают в 25\% населения разных стран [1]. На ЖГ приходится до 70\% всех болезней печени. При этой патологии клетки печени перерождаются в жировую ткань. Наиболее распространенными причинами ЖГ являются избыточный вес, переедание, злоупотребление высококалорийной пищей [2]. Высокая социальная и медицинская значимость проблемы ЖГ обусловлена тем, что он может привести к стеатогепатиту с последующим прогрессированием в фиброз и цирроз печени, которые значительно снижают качество жизни человека, приводят к длительной и стойкой утрате трудоспособности [3]. Увеличение распространенности ЖГ, малосимптомность клинической картины и недостаточное знание патогенеза этого заболевания, методов его профилактики и лечения, а также тяжесть его осложнений ставят эту проблему в ряд важнейших медико-социальных [4].

Экспериментальные модели ЖГ используются для изучения механизмов формирования, выяснения роли различных факторов внешней и внутренней среды в становлении патологических процессов в печени, а также позволяют детально изучить патогенез и изыскать средства для рациональной терапии и профилактики. Существует несколько разновидностей методов моделирования ЖГ у животных: 1) метионин-холин-дефицитная диета [5]; 2) диета с высоким содержанием жиров или углеводов, а также их комбинация [6]; 3) моделирование лекарственного ЖГ [7]; 4) использование химических токсических веществ [8] и т.д. Каждая из данных моделей имеет как свои преимущества, так и недостатки.

На наш взгляд, экспериментальный рацион с повышенным содержанием жиров и углеводов в наибольшей степени соответствует рациону питания людей, страдающих ЖГ. Такая комбинированная алиментарная модель ЖГ у лабораторных крыс может точнее воспроизводить основные проявления данного заболевания и механизмы его развития. Вместе с тем следует учитывать, что результаты моделирования ЖГ на животных с помощью высококалорийной диеты зависят также от целого ряда других факторов: генотипа, пола и возраста животного, а также типа, вида и продолжительности воздействия такой диеты. Поэтому создание подобныхживотных моделей ЖГ остается по-прежнему актуальной задачей экспериментальной медицины [9].

\section{ЦЕЛЬ ИССЛЕДОВАНИЯ}

Создание экспериментальной модели жирового гепатоза и сравнение эффективности ее воспроизведения на крысах разного возраста.

\section{МАТЕРИАЛЫ И МЕТОДЫ}

Место и время проведения исследования

Место проведения. Исследование проведено на крыcax-самцах линии Wistar, взятых из питомника вивария.

Время исследования. Эксперимент проведен с сентября по ноябрь 2020 г. включительно. Продолжительность моделирования ЖГ составляла 12 нед.

Изучаемые популяции (одна или несколько)

Изучалась одна популяция.

Критерии включения: для участия в исследовании были отобраны самцы крыс линии Wistar в возрасте 3 мес

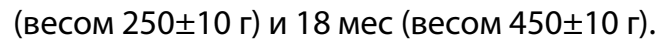

Критерии исключения и прекращения участия в исследовании не применялись.

\section{Дизайн исследования}

Проведено экспериментальное одноцентровое проспективное одновыборочное контролируемое рандомизированное исследование без ослепления. Рандомизация проводилась блочным методом со стратификацией по возрасту и весу животных.

\section{Анализ в подгруппах}

Животные были разделены на 4 группы (по 12 животных в каждой): I и III - контрольные 3- и 18-месячные животные, II и IV - подопытные молодые и взрослые крысы соответственно. Крыс в группы набирали с использованием одинаковых критериев (пол, возраст и вес).

Описание моделирования патологического процесса

Подопытные крысы в течение 12 нед содержались на рационе с избыточным содержанием жиров (45\%) и углеводов (31\%). Каждая крыса получала 6 г специально приготовленного гранулированного корма (70\% стандартного комбикорма с добавлением 30\% свиного смальца); 6,8 г свиного сала, 3,6 г белых сухарей; 3,6 г семян подсолнечника, что суммарно составляло 116 ккал. Подопытные животные получали корм ad libitum под ежедневным контролем полноты его поедания. Через день вместо воды подопытные крысы получали 10\% раствор фруктозы. Контрольные животные находились на стандартном рационе питания. Крыса контрольной группы ежедневно съедала 20 г комбикорма, калорийность которого составляла 66 ккал.

Наличие ЖГ, функциональную активность, физиологическую регенерацию и состояние паренхимы и соединительной ткани в печени оценивали с помощью физиологических, цитоморфометрических, морфологических, биохимических и биофизических методов исследования. Массу тела, висцерального жира и печени измеряли гравиметрически. Крыс выводили из эксперимента путем декапитации под эфирным наркозом. 


\section{Основные критерии исследования}

При использовании модели ЖГ основными критериями стали морфологические изменения печени, а именно: средний диаметр, площадь поперечного сечения гепатоцитов, их ядер и цитоплазмы; ядерно-цитоплазматическое соотношение; количество одно- и двуядерных клеток и плотность их размещения (на единицу площади

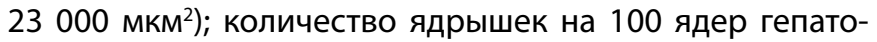
цитов и ядрышко-ядерное соотношение; относительная площадь сетки синусоидов, паренхимы печени и больших липидных капель; коэффициент Vizotto (отношение относительной площади сетки синусоидов к относительной площади паренхимы печени); количество и плотность размещения клеток соединительной ткани на единицу площади (23000 мкм²) [10, 11].

К основным биохимическим критериям можно отнести изменение концентрации липидов, холестерина и триглицеридов в ткани печени, и также изменение активности аланинаминотрансферазы (АЛТ) в сыворотке крови.

К основным биофизическим критериям можно отнести изменение результатов мультичастотной биоимпедансометрии печени, а именно: величины импеданса, реактивного сопротивления и коэффициентов дисперсии реактивного сопротивления.

\section{Методы регистрации критериев}

Для морфологических и морфометрических исследований ЖГ отбирали образцы ткани печени, из которых изготавливали гистологические препараты по стандартной методике: фиксировали в жидкости Буэна, обезвоживали в спиртах возрастающей концентрации (от $70^{\circ}$ до $\left.96^{\circ}\right)$ и диоксане. Полученные образцы заливали в парафин. Парафиновые срезы толщиной 6 мкм изготавливали на санном микротоме. Окраску полученных срезов осуществляли обзорными красителями: гематоксилином Бемера и эозином. Для визуализации элементов соединительной ткани применяли метод окраски по ВанГизону [12]. С использованием цифровой камеры микропрепараты фотографировали на микроскопе Nikon Eclipse E100 (Япония). Морфометрию на цифровых изображениях микропрепаратов осуществляли с помощью компьютерной программы IMAGE J.

Из навески печени смесью хлороформ-метанол делали экстракт, в котором фотометрически определяли маркеры ЖГ, а именно: концентрацию липидов, холестерина и триглицеридов. Кинетическим методом Райтмана-Френкеля в сыворотке крови на биохимическом анализаторе (Sinnowa, KHP) измеряли активность АЛТ. Определение данных биохимических показателей производили с помощью стандартных наборов реактивов («Филисит-Диагностика», Украина).

Для оценки биофизических свойств печеночной ткани использовали метод мультичастотной биоимпедансометрии (БИМ) [13]. БИМ-тестирование препаратов свежевыделенной печени проводили еx tempore на LCRmeter Quad Tech 1920 (США) в режиме работы прибора с параллельной эквивалентной схемой. Абсолютные величины электрических параметров определяли на частотах 100 Гц - 1 МГц. Измерение проводили с использованием 2 плоских серебряных электродов площадью

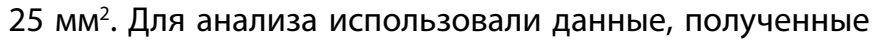

на частотах максимальной и минимальной поляризаций объекта ( $10^{4}$ и $10^{6}$ Гц). В ходе анализа полученных данных рассчитывали коэффициенты дисперсии реактивного сопротивления как отношение его величин, измеренных на низкой и высокой частотах (DXc $10^{4} / 10^{6}$ Гц).

\section{Статистический анализ}

Полученные данные обрабатывали с помощью программного обеспечения Statistica 6.0 for Windows (StatSoft, USA) и программы Excel 2010 (Microsoft, USA). Нормальность распределения цифровых массивов проверяли, используя критерий Пирсона. При нормальном распределении для оценки коэффициента достоверности различий между контрольной и подопытной группой использовали t-критерий Стьюдента (данные представлены в виде среднее ошибка средней). Различия считали достоверными при значении $\mathrm{p}<0,05$.

\section{Этическая экспертиза}

Исследования проводили в соответствии с положениями «Европейской конвенции о защите позвоночных животных, используемых для экспериментальных и других научных целей» (Страсбург, 1986). Протокол исследований также был одобрен комитетом по биомедицинской этике Института физиологии им. А.А. Богомольца НАН Украины (протокол № 5 от 31.11.19).

\section{РЕЗУЛЬТАТЫ}

\section{Объекты исследования}

Исследование проведено на 48 крысах-самцах линии Wistar, возраст которых в начале эксперимента составлял 3 и 18 мес. Крысы всех групп находились в унифицированных условиях. Животные были разделены на 4 группы (по 12 животных в каждой): I и III - контрольные 3- и 18-месячные животные, II и IV - подопытные молодые и взрослые крысы соответственно. В нашем исследовании ЖГ на конец эксперимента был диагностирован у $100 \%$ крыс. Перед началом эксперимента проводились анализ выборки и оценка состоятельности перед включением в исследование. При данном анализе была определена однородность выборки в каждой группе по исходным показателям веса.

\section{Основные результаты исследования}

У всех крыс, которые в течение 12 нед находились на высококалорийном рационе (ВР), при макроскопическом исследовании было обнаружено существенное увеличение размеров печени. Она имела дряблую консистенцию, тургор паренхимы был снижен. Поверхность печени была гладкой и имела различные оттенки желтого цвета (от желто-беловатого до охряно-желтого). У большинства крыс такая окраска была диффузной и распространялась на всю поверхность печени, а у некоторых она чередовалась с участками печени, имевшими нормальную (красно-бурую) окраску.

Выявлено, что у 6-месячных крыс подопытной группы абсолютная и относительная масса печени были достоверно больше, чем у контрольных, на 34 и 23\% соответственно. У 21-месячных животных масса печени возросла на 19\% (абсолютная) и 22\% (относительная). Масса висцерального жира у подопытных крыс существенно 


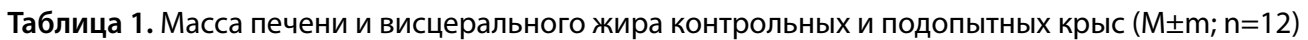

\begin{tabular}{lcccc}
\hline \multicolumn{1}{c}{ Показатели } & \multicolumn{2}{c}{ 6-месячные крысы } & \multicolumn{2}{c}{ 21-месячные крысы } \\
& Контроль & Опыт & Контроль & Опыт \\
\hline Масса печени & & & & \\
абсолютная, г & $8,8 \pm 0,2$ & $11,8 \pm 0,7^{*}$ & $9,4 \pm 0,7$ & $11,2 \pm 0,7^{*}$ \\
относительная, \% & $2,2 \pm 0,1$ & $2,7 \pm 0,1^{*}$ & $2,3 \pm 0,1$ & $2,8 \pm 0,2^{*}$ \\
\hline Масса висцерального жира & & & & \\
абсолютная, г & $19,0 \pm 1,1$ & $46,6 \pm 1,7^{*}$ & $23,9 \pm 1,6$ & $37,7 \pm 1,0^{*}$ \\
относительная, \% & $4,7 \pm 0,8$ & $10,8 \pm 0,7^{*}$ & $5,9 \pm 0,7$ & $9,3 \pm 0,8^{*}$ \\
\hline
\end{tabular}

Примечание. Здесь и в табл. 2-4. * $p<0,05$ - достоверность различий по сравнению с контролем.

увеличилась, а именно: у 6-месячных - на 145\% и у 21 -месячных — на $58 \%$ (табл. 1).

При анализе гистологических препаратов ткани печени отмечено, что животные, получавшие ВР, имели нарушенную структуру паренхимы печени. Гепатоциты с хорошо выраженной мембраной, среднего и большого размера. Ядра гепатоцитов округлой формы, размещенные преимущественно в центре клетки, иногда - на периферии, за счет смещения их большими липидными каплями. Ядерная мембрана сохранена и имела четкие очертания. В паренхиме печени обнаружены обширные области с признаками жировой дистрофии гепатоцитов в виде многочисленных липидных капель различного размера. Множественные липидные капли имели тенденцию к слиянию и образовывали крупные жировые капли площадью более 100 мкм². Цитоплазма имела многочисленные липидные включения. Ядрышки были округлой формы, среднего и мелкого размера. В синусоидах встречались макрофаги. В печени подопытных крыс местами наблюдались гибель гепатоцитов и замещение пустот крупными каплями жира. Все эти изменения в структуре печени указывают на наличие выраженного ЖГ II степени, где более половины гепатоцитов подверглись жировой дистрофии (рис. 1 и 2).
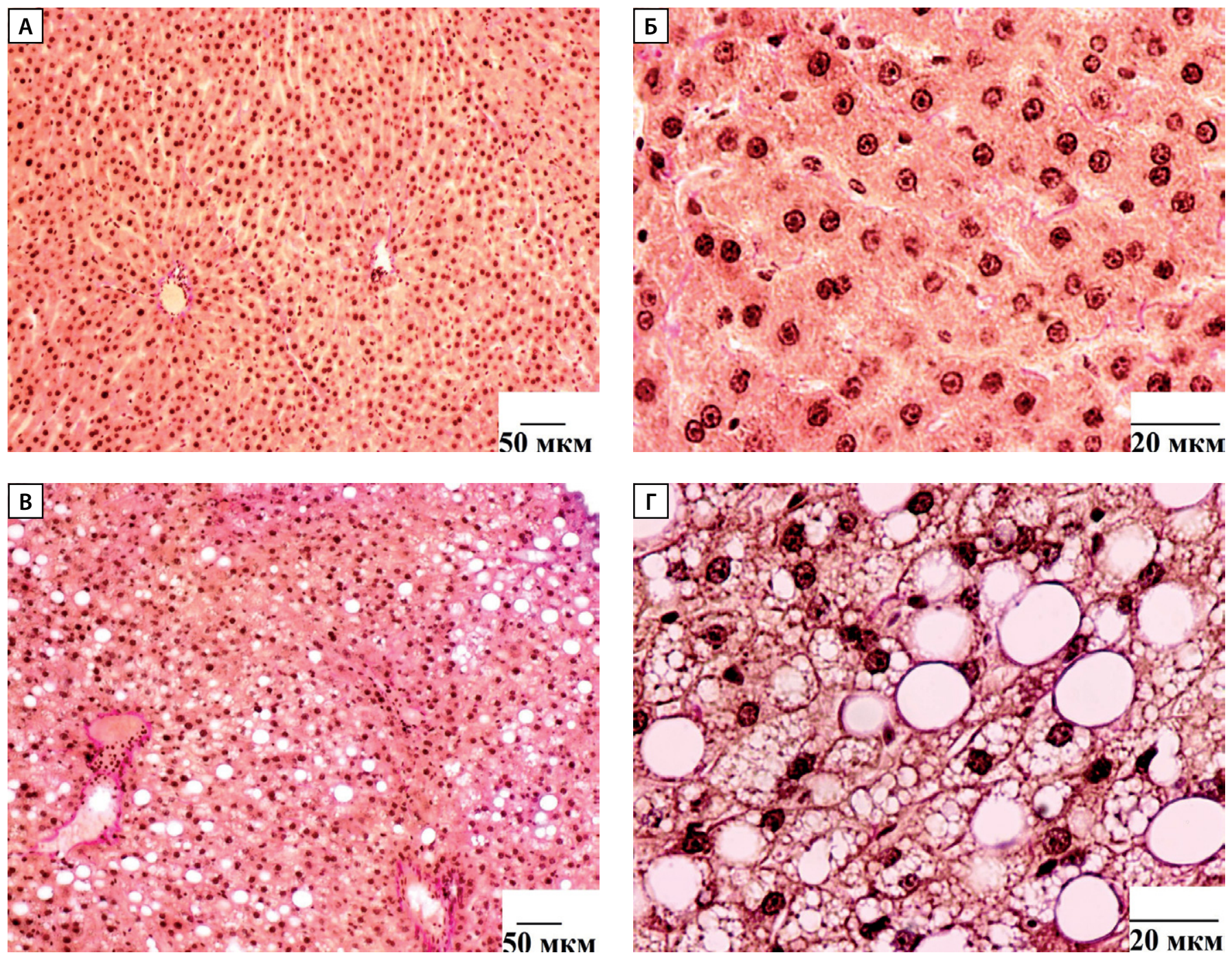

Рисунок 1. Микрофотография печени контрольной (A - х200, Б - х800) и подопытной (B - х200, Г - х800) крысы 6-месячного возраста. Окраска по Ван-Гизону. 

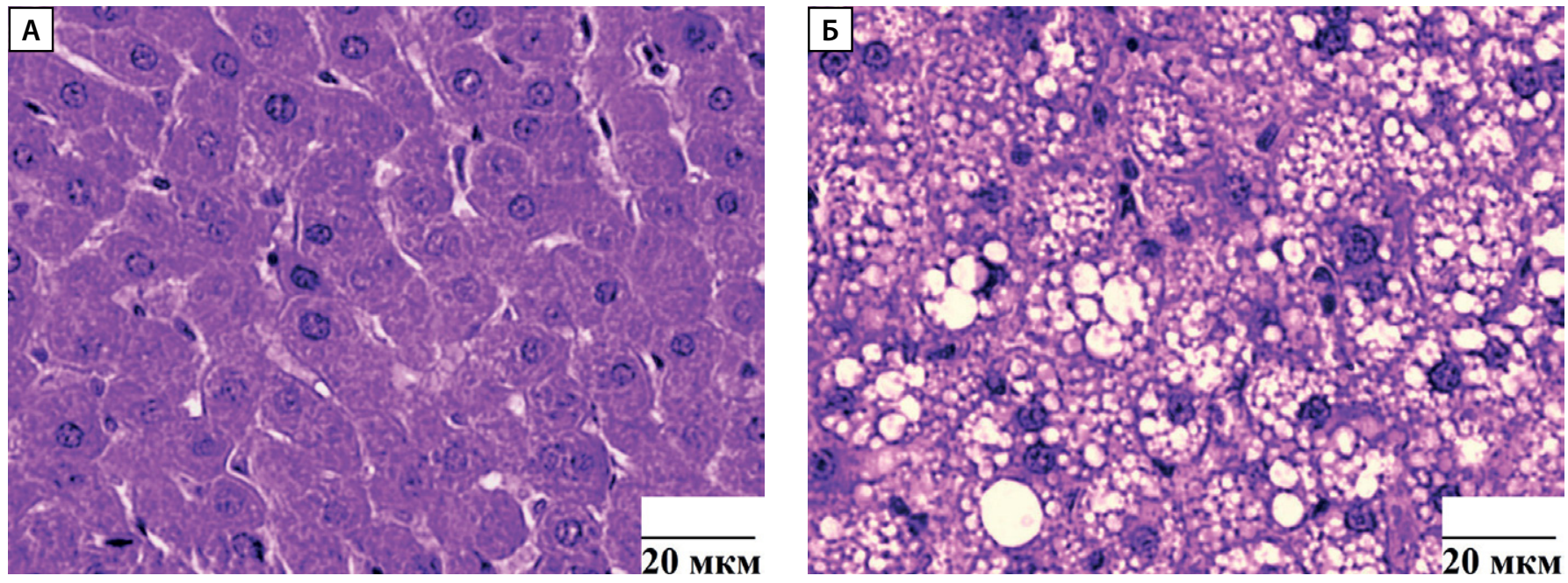

Рисунок 2. Микрофотография печени контрольной (А) и подопытной (Б) крысы 21-месячного возраста. Окраска гематоксилином Бемера и эозином. $\mathbf{x} 800$.

В печени крыс с моделированным ЖГ выявлены существенные морфометрические изменения. Так, в печени 6и 21-месячных подопытных крыс наблюдали уменьшение относительной площади паренхимы печени на 8 и 29\% $(p<0,05)$ соответственно, в сравнении с группой контроля. У 6-месячных крыс выявлено достоверное увеличение размеров гепатоцитов, а именно: среднего диаметра на 19\%, площади - на 34\% и площади цитоплазмы клеток - на 38\% по сравнению с контролем. Площадь ядра оставалась на контрольном уровне, что привело к достоверному снижению ядерно-цитоплазматического соотношения на 19\%. В печени 21-месячных подопытных крыс также наблюдали достоверное увеличение среднего диаметра (на 12\%), площади гепатоцитов (на 25\%), их цитоплазмы (на 28\%) и снижение ядерно-цитоплазматического соотношения (на 17\%) (табл. 2). Гипертрофия гепатоцитов была связана с накоплением в них липидных включений.

Состояние ядрышкового аппарата является важным информационным показателем функциональной активности гепатоцитов. У 6-месячных животных, подвергавшихся воздействию ВР, было отмечено достоверное уменьшение на $41 \%$ количества ядрышек в ядрах гепатоцитов и ядрышко-ядерного соотношения - на $46 \%$ по сравнению с контролем. У 21-месячных подопытных крыс количество ядрышек не изменялось (см. табл. 2).

В печени подопытных животных общее количество и количество одноядерных гепатоцитов на единицу площади было достоверно меньшим от контрольных значений на 25 и 26\% - у 6-месячных крыс и на 24 и $25 \%$ соответственно у 21-месячных животных. Количество двуядерных гепатоцитов достоверно снизилось лишь у молодых крыс на $19 \%$ (см. табл. 2).

Количество крупных (>100 мкм²) липидных капель в печени 6-месячных крыс с ЖГ на единицу площади (93 тыс. мкм² - площадь микрофотографии при увеличении в 400 раз) в среднем составляло 10,8. А количество больших липидных капель в печени 21-месячных животных было 14,8, что на 37\% больше, чем у молодых крыс. При этом относительная площадь крупных капель у молодых крыс в среднем составляла 13,4\%, а у взрослых крыс - 30,8\% площади паренхимы печени (см. табл. 2).

Сеть синусоидов в печени подопытных крыс была слабо выражена, что является признаком нарушения кровообращения и лимфотока. Так, у 6-месячных животных выявили достоверно меньшую относительную площадь сети синусоидов (на 61\%) и коэффициента Vizotto (на 57\%). У 21-месячных крыс, находившихся на ВР, площадь синусоидов и коэффициент Vizotto были достоверно ниже, на 39 и 13\% соответственно (см. табл. 2). Синусоиды образуют сеть соединенных между собой сосудов. Уменьшение их относительной площади свидетельствует о худшем кровенаполнении паренхимы печени и деактивации трофической функции соединительной ткани в ней.

В печени молодых животных с моделированным ЖГ общее количество и плотность расположения клеток соединительной ткани (на единицу площади) были достоверно меньше на 33 и 32\% соответственно по сравнению с контролем. Исследуемые показатели соединительной ткани в печени 21-месячных подопытных крыс были ниже на $16 \%(p<0,05)$ (см. табл. 2).

В метаболизме липидов важная роль принадлежит печени. В ней происходит гидролиз липидов на глицерин и жирные кислоты. Около 50\% холестерина синтезируется именно в печени. Показано, что при алиментарном ожирении практически у всех пациентов развивается ЖГ, когда более 5\% массы органа составляет жир, который накапливается в гепатоцитах в виде триглицеридов [14]. Выявлено, что в печени подопытных крыс обеих возрастных групп достоверно возрастает концентрация маркеров ЖГ, а именно: липидов, триглицеридов и общего холестерина. У 6-месячных крыс эти показатели увеличивались более существенно, чем у 21-месячных животных. Так концентрация липидов в печени 6-месячных крыс стала большей на 177\%, а 21-месячных - на $127 \%$ сравнительно с контролем. Концентрация общего холестерина в печени 6- и 21-месячных животных увеличилась на 111 и 81\% соответственно. Концентрация триглицеридов, наоборот, более значительно выросла в печени 21-месячных крыс по сравнению с 6-месячными - на 200\% и $114 \%$ соответственно по сравнению с контролем. Проведенные нами исследования показали достоверное увеличение активности АЛТ в сыворотке крови 6-месячных подопытных крыс на 37\%. У 21-месячных крыс активность АЛт не имела существенных отличий от контрольных значений (табл. 3). 


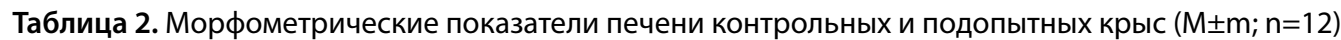

\begin{tabular}{|c|c|c|c|c|}
\hline \multirow{2}{*}{ Показатели } & \multicolumn{2}{|c|}{ 6-месячные крысы } & \multicolumn{2}{|c|}{ 21-месячные крысы } \\
\hline & Контроль & Опыт & Контроль & Опыт \\
\hline Средний диаметр гепатоцита, мкм & $15,7 \pm 0,3$ & $18,7 \pm 0,4^{*}$ & $15,1 \pm 0,4$ & $16,9 \pm 0,6^{*}$ \\
\hline \multicolumn{5}{|l|}{ Площадь, мкм² } \\
\hline гепатоцита & $255,1 \pm 10,6$ & $342,2 \pm 9,3^{*}$ & $239,7 \pm 14,2$ & $299,7 \pm 16,1^{*}$ \\
\hline ядра & $34,7 \pm 1,8$ & $38,6 \pm 1,6$ & $35,8 \pm 2,3$ & $39,4 \pm 1,9$ \\
\hline цитоплазмы & $220,4 \pm 10,1$ & $303,6 \pm 8,5^{*}$ & $203,9 \pm 12,5$ & $260,3 \pm 13,8^{*}$ \\
\hline Ядерно-цитоплазм. соотношение & $0,160 \pm 0,008$ & $0,130 \pm 0,007^{*}$ & $0,180 \pm 0,009$ & $0,150 \pm 0,008^{*}$ \\
\hline \multicolumn{5}{|l|}{$\begin{array}{l}\text { Количество гепатоцитов, шт. (на площадь } \\
23000 \text { мкм²) }\end{array}$} \\
\hline общее & $67,3 \pm 1,9$ & $50,3 \pm 1,6^{*}$ & $68,3 \pm 3,5$ & $51,9 \pm 5,4^{*}$ \\
\hline одноядерных & $65,3 \pm 2,0$ & $48,6 \pm 1,5^{*}$ & $65,0 \pm 2,7$ & $48,9 \pm 5,2^{*}$ \\
\hline двуядерных & $2,1 \pm 0,1$ & $1,7 \pm 0,1^{*}$ & $3,3 \pm 0,5$ & $3,0 \pm 0,1$ \\
\hline $\begin{array}{l}\text { Соотношение двуядерные/одноядерные } \\
\text { гепатоциты }\end{array}$ & $0,032 \pm 0,004$ & $0,035 \pm 0,005$ & $0,051 \pm 0,002$ & $0,061 \pm 0,007^{*}$ \\
\hline $\begin{array}{l}\text { Плотность размещения гепатоцитов, } \\
\text { шт./1000 мкм² }\end{array}$ & $2,93 \pm 0,08$ & $2,2 \pm 0,1^{*}$ & $2,97 \pm 0,05$ & $2,26 \pm 0,13^{*}$ \\
\hline Количество ядрышек в ядре гепатоцита, шт. & $2,40 \pm 0,09$ & $1,42 \pm 0,05^{*}$ & $2,10 \pm 0,2$ & $2,07 \pm 0,29$ \\
\hline Ядрышко-ядерное соотношение & $0,069 \pm 0,003$ & $0,037 \pm 0,001^{*}$ & $0,059 \pm 0,008$ & $0,053 \pm 0,009$ \\
\hline 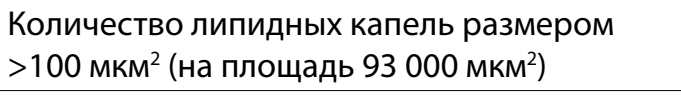 & - & $10,8 \pm 0,9$ & - & $14,8 \pm 1,1$ \\
\hline Относительная площадь паренхимы, \% & $87,8 \pm 0,9$ & $81,2 \pm 1,3$ & $86,3 \pm 0,8$ & $60,9 \pm 5,7^{*}$ \\
\hline $\begin{array}{l}\text { Относительная площадь липидных капель } \\
(\text { размером > } 100 \text { мкм²), \% }\end{array}$ & - & $13,4 \pm 1,4$ & - & $30,8 \pm 0,5$ \\
\hline \multicolumn{5}{|c|}{ Соединительная ткань } \\
\hline $\begin{array}{l}\text { Относительная площадь сетки } \\
\text { синусоидов, \% }\end{array}$ & $12,2 \pm 0,8$ & $4,8 \pm 0,3^{*}$ & $13,7 \pm 0,8$ & $8,3 \pm 0,5^{*}$ \\
\hline Коэффициент Vizotto & $0,14 \pm 0,01$ & $0,060 \pm 0,003^{*}$ & $0,16 \pm 0,01$ & $0,14 \pm 0,01^{*}$ \\
\hline $\begin{array}{l}\text { Количество клеток соединительной ткани, } \\
\text { шт. (на площадь } 23000 \text { мкм²) }\end{array}$ & $22,2 \pm 1,5$ & $14,9 \pm 1,3^{*}$ & $22,2 \pm 1,3$ & $18,7 \pm 1,4^{*}$ \\
\hline $\begin{array}{l}\text { Плотность размещения клеток } \\
\text { соединительной ткани шт./1000 мкм² }\end{array}$ & $0,96 \pm 0,02$ & $0,65 \pm 0,05^{*}$ & $0,97 \pm 0,02$ & $0,81 \pm 0,03^{*}$ \\
\hline $\begin{array}{l}\text { Соотношение количество клеток соед. } \\
\text { ткани/количество гепатоцитов }\end{array}$ & $0,33 \pm 0,03$ & $0,30 \pm 0,03$ & $0,33 \pm 0,03$ & $0,36 \pm 0,01$ \\
\hline
\end{tabular}

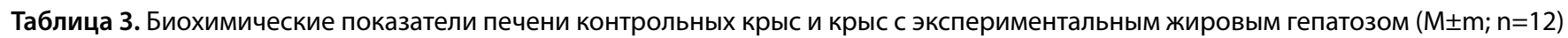

\begin{tabular}{|c|c|c|c|c|}
\hline \multirow{2}{*}{ Показатели } & \multicolumn{2}{|c|}{ 6-месячные крысы } & \multicolumn{2}{|c|}{ 21-месячные крысы } \\
\hline & Контроль & Oпыт & Контроль & Опыт \\
\hline Липиды, мг/г & $18,9 \pm 1,5$ & $52,3 \pm 1,9^{*}$ & $17,1 \pm 0,9$ & $38,8 \pm 2,2 *$ \\
\hline Триглицериды, мг/г & $0,36 \pm 0,05$ & $0,77 \pm 0,09 *$ & $5,2 \pm 0,4$ & $15,6 \pm 0,4^{*}$ \\
\hline $\begin{array}{l}\text { Холестерин общий, } \\
\text { мкмоль/г }\end{array}$ & $3,8 \pm 0,2$ & $8,0 \pm 0,4^{*}$ & $3,6 \pm 0,2$ & $6,5 \pm 0,5^{*}$ \\
\hline Активность АЛТ, Ед/л & $63,6 \pm 4,0$ & $87,1 \pm 4,7^{*}$ & $68,6 \pm 4,3$ & $65,0 \pm 4,9$ \\
\hline
\end{tabular}


Таблица 4. Показатели мультичастотной биоимпедансометрии печеночной ткани контрольных крыс и крыс с экспериментальным жировым гепатозом ( $\mathrm{M} \pm \mathrm{m} ; \mathrm{n}=12)$

\begin{tabular}{|c|c|c|c|c|c|c|}
\hline \multirow{2}{*}{$\begin{array}{l}\text { Возраст } \\
\text { крыс, } \\
\text { мес }\end{array}$} & \multirow[t]{2}{*}{ Группа } & \multicolumn{2}{|c|}{ Импеданс, Ом } & \multicolumn{2}{|c|}{$\begin{array}{l}\text { Реактивное сопротивление, } \\
\text { Ом }\end{array}$} & \multirow{2}{*}{$\begin{array}{l}\text { Коэф. дисперсии } \\
\text { реактивного } \\
\text { сопротивления }\end{array}$} \\
\hline & & $10^{4} \Gamma 4$ & $10^{6} \mathrm{\Gamma L}$ & $10^{4} \Gamma 4$ & $10^{6} \mathrm{\Gamma u}$ & \\
\hline \multirow{2}{*}{6} & Контроль & $1377 \pm 49$ & $330 \pm 22$ & $3236 \pm 148$ & $787 \pm 55$ & 4,1 \\
\hline & Опыт & $2068 \pm 121^{*}$ & $480 \pm 55$ & $5325 \pm 227^{*}$ & $1760 \pm 174^{*}$ & 3,0 \\
\hline \multirow{2}{*}{21} & Контроль & $1900 \pm 91^{\#}$ & $398 \pm 12^{\#}$ & $4213 \pm 212^{\#}$ & $1002 \pm 33^{\#}$ & 4,2 \\
\hline & Опыт & $2015 \pm 154$ & $416 \pm 24$ & $4061 \pm 191^{\#}$ & $1075 \pm 81^{\#}$ & 3,8 \\
\hline
\end{tabular}

Примечание. ${ }^{\#}$ < 0,05 - достоверность различий по сравнению с 6-месячными крысами.

Результаты БИМ показали, что у молодых крыс контрольной группы величины импеданса и реактивного сопротивления печеночной ткани были достоверно на 21-17 и 23-21\% соответственно меньше как на низких, так и на высоких частотах тестирующего тока, чем у контрольных крыс старшей возрастной группы (табл. 4). Это может быть обусловлено возрастными изменениями печеночной ткани (увеличение содержания жира и соединительнотканных элементов). Однако межгрупповых различий коэффициентов дисперсии реактивного сопротивления не отмечалось, что свидетельствовало о сохранении способности клеток печени к поляризации при пропускании через них тестирующего тока.

Наиболее существенные изменения показателей БИМ при развитии ЖГ наблюдали у молодых крыс. Величина импеданса достоверно увеличивалась на 50-45\%, а реактивного сопротивления - на 65-124\% как на низких, так и на высоких частотах тестирующего тока. Аналогичный характер направленности изменений показателей БИМ отмечался и в группе подопытных крыс старшей возрастной группы, однако эти изменения не достигали статистически значимых величин. Характерно, что в обеих группах подопытных крыс отмечалось снижение коэффициента дисперсии реактивного сопротивления, однако у молодых животных это снижение было выражено в большей степени (см. табл. 4). Результаты БИМ-исследований печеночной ткани подопытных крыс свидетельствуют о том, что использованная экспериментальная модель ЖГ приводит к развитию выраженной жировой дистрофии печеночной ткани как у молодых (в большей степени), так и старых крыс. Об этом свидетельствует увеличение импеданса и реактивного сопротивления печеночной паренхимы, особенно на частоте 10 кГц, а также снижение коэффициента частотной дисперсии реактивного сопротивления.

Нежелательные явления

В ходе исследования нежелательных явлений отмечено не было.

\section{ОБСУЖДЕНИЕ}

Резюме основного результата исследования

Предложенная нами модель ЖГ на основе комбинированного (жироуглеводного) ВР у всех лабораторных крыс приводит к развитию выраженных морфологических, биохимических и биофизических признаков данной патологии. Наибольшей степени выраженности основные признаки ЖГ достигают у молодых животных. Показатель воспроизводимости ЖГ при использовании данной модели в течение 12 нед достигает 100\%.
Обсуждение основного результата исследования

Проблема диагностики, лечения и профилактики ЖГ является одной из актуальных проблем современной медицины. Особое внимание клиницистов обращено на развитие начальных стадий данного заболевания у детей и лиц молодого возраста. Это обусловлено тем, что, с одной стороны, отдаленные последствия развития ЖГ у молодых людей наиболее опасны и наименее прогнозируемы. С другой стороны, у молодых людей на начальных стадиях заболевания еще отсутствуют грубые нарушения морфофункционального состояния печеночной ткани, которые наблюдаются у лиц старшего возраста при развитии воспалительных и склеротических процессов (стеатогепатита и фиброза), а эффективность лечебных мероприятий наиболее высока. В этой связи возникает потребность в создании надежных экспериментальных моделей ЖГ, которые были бы максимально приближены к патогенетическим закономерностям развития данного заболевания у человека.

Цель нашей работы заключалась в том, чтобы создать простой и надежный способ моделирования ЖГ у крыс, который, с одной стороны, позволял бы с высокой эффективностью воспроизводить жировое перерождение печени, а с другой, по своим основным этиологическим и патогенетическим характеристикам, максимально бы соответствовал ЖГ, развивающемуся у человека при гиперкалорийном питании. Принципиально важным было подтвердить возможность воспроизведения основных патогномоничных симптомов ЖГ на такой модели. Для этого нами был использован комплекс гистоморфометрических, биохимических и биофизических методов исследования. Мы разработали экспериментальную модель ЖГ, которая максимально отвечает данным требованиям. Для повышения эффективности воспроизведения ЖГ была использована комбинированная алиментарная модель. В ее основе - высококалорийный рацион питания с повышенным содержанием жиров и углеводов, поскольку в большинстве случаев именно такой рацион является причиной развития алиментарного ЖГ у людей.

В качестве дополнительного источника животных жиров мы использовали свиной смалец, который добавляли к основному корму, а также свежее свиное сало. Растительные жиры вводились в рацион в виде подсолнечного масла и семян подсолнечника. Дополнительным источником легкоусвояемых углеводов служили 10\% раствор фруктозы и белый хлеб. В экспериментах на лабораторных крысах было показано, что добавка фруктозы усугубляет отрицательное влияние рациона питания с высоким содержанием жиров на развитие стеатоза печени 
и метаболизм липидов в целом [15]. Представлены новые данные о том, что фруктоза участвует в метаболизме липидов, способствует накоплению жира или уменьшает его элиминацию из печени [16].

Однако ни одна модель ЖГ алиментарного происхождения не может быть воспроизведена в полной мере, если предлагаемый животному корм не будет полностью потреблен. Для надежного воспроизведения модели ЖГ необходимо, чтобы показатель потребления корма приближался к своему максимуму - 100\%. В этой связи мы ежедневно контролировали полноту потребления животными высококалорийного корма и при необходимости стимулировали этот процесс с помощью естественных пищевых аттрактантов.

Как известно, крысы относятся к животным, обладающим острым обонянием и вкусом. Поэтому с целью повышения поедаемости корма экспериментаторы часто прибегают к использованию различных ароматических добавок и усилителей вкуса, таких как глутамат натрия, ванилин и т.п. В нашей модели мы отказались от каких-либо искусственных пищевых аттрактантов, а использовали только естественные продукты и вещества. Так, сало является одним из естественных пищевых аттрактантов не только для крыс, но и других грызунов. Для повышения потребления корма животными мы брали только свежее сало с прослойками мяса и подвергали его легкому копчению. С той же целью белый хлеб давали в виде сухарей, которые непосредственно перед раздачей корма опрыскивали нерафинированным растительным маслом, а семена подсолнечника слегка поджаривали. В нашей модели ЖГ мы отдали предпочтение использованию 10\% раствора фруктозы в чередовании с приемом обычной воды. Это было обусловлено тем, что (как показали наши предварительные наблюдения) при использовании растворов фруктозы высокой концентрации животные существенно снижали потребление не только сухих кормов, но и жидкости, что создавало угрозу нарушения водного баланса организма.

Все эти меры были успешно реализованы в нашей модели ЖГ. Они способствовали существенному увеличению потребления корма экспериментальными животными (коэффициент потребления корма достигал 97-100\%) и обеспечивали поддержание нормального водного баланса организма. Результаты наших исследований свидетельствуют о том, что разработанная модель на основе ВР воспроизводит основные патогномоничные симптомы ЖГ как у молодых (в большей степени), так и у взрослых крыс.

О наличии ЖГ свидетельствуют увеличение массы печени, ее бледноватый оттенок и мягкая консистенция. К морфометрическим признакам, которые указывают на наличие ЖГ и снижение функциональной активности печени, можно отнести гипертрофию гепатоцитов с одновременным снижением ядерно-цитоплазматического соотношения. Гипертрофия клеток связана с накоплением в цитоплазме многочисленных липидных включений. Также в печени этих крыс наблюдали появление крупных липидных капель, которые существенно изменяли структуру печени, замещали пустоты погибших гепатоцитов. У подопытных крыс достоверно снизилось количество двуядерных гепатоцитов и ядрышек в ядрах, что свидетельствует о снижении интенсивности внутриклеточных регенерационных процессов в паренхиме печени [17].
Гипоплазия ядрышек также свидетельствует о снижении белок-синтетической активности гепатоцитов [18]. Сеть синусоидов в печени подопытных крыс слабо выражена, что говорит о худшем кровенаполнении паренхимы печени, о деактивации трофической функции соединительной ткани в ней. Уменьшение количества и плотности расположения клеток соединительной ткани в печени подопытных крыс может указывать на снижение защитной функции стромы.

Возрастание концентрации липидов, холестерина и триглицеридов в ткани печени подопытных крыс свидетельствует о развитии ЖГ, который в дальнейшем может привести к стеатогепатиту и циррозу печени. При ожирении, вследствие увеличения массы висцерального жира, усиливается утилизация глюкозы, активируется липолиз и липогенез, что ведет к возрастанию поступления свободных жирных кислот в портальный кровоток, а затем и в печень. В печени часть свободных жирных кислот этерифицируется с образованием триглицеридов, а часть вступает в реакции $\beta$-окисления, затем в цикл Кребса с образованием аденозинтрифосфата. При большом количестве жирных кислот образуется избыток триглицеридов, холестерина и липопротеинов очень низкой плотности, увеличивается их содержание в крови, а также накопление в гепатоцитах [6]. Увеличение активности АЛТ в сыворотке крови молодых животных может свидетельствовать о разрушении и повреждении клеток [19]. Полученные нами данные об изменениях активности АЛТ подтверждаются клиническими исследованиями, в которых было выявлено более быстрое и значительное повышение активности этого фермента при заболеваниях печени, таких как вирусный гепатит, хроническое поражение печени и ЖГ. Активность АЛТ возрастает при повышении степени гепатоза [20].

Как известно, нормальная печеночная ткань состоит в основном из паренхиматозных клеток - гепатоцитов и небольшого количества соединительнотканных элементов, образующих ее строму. Она имеет высокую электропроводность и низкое сопротивление электрическому току. Жировая же ткань, напротив, относится к биологическим тканям, обладающим низкой электропроводностью и высоким электрическим сопротивлением. Такие различия биоэлектрических свойств печеночной и жировой ткани создают предпосылки для возможности идентификации накопления жира в печени методом БИМ. Очевидно, что при повышении содержания жира в печени при развитии ЖГ могут изменяться ее импедансометрические показатели, поскольку жир имеет очень высокое сопротивление электрическому току. В исследованиях ряда авторов показано, что метод БИМ позволяет определять не только количество жировой ткани, но и половые различия в ее свойствах и структуре [21]. Проведенные нами БИМ-исследования подтвердили, с одной стороны, высокую надежность разработанной модели ЖГ, а с другой перспективность использования метода БИМ для диагностики жировой дистрофии печени.

В литературе имеется ряд работ, в которых описываются похожие модели ЖГ, но с некоторыми отличиями. Показано, что содержание мышей линии C57/BL6 в течение 8 нед на коммерческом корме (New Brunswick, NJ, USA) с 60\% содержанием жира приводит к появлению ЖГ, о чем свидетельствуют наличие больших липидных 
капель в печени, увеличение ее массы, возрастание активности АЛТ и т.д. [22]. Содержание крыс линии Wistar в течение 18 нед на рационе с 35\% содержанием жира приводит к увеличению концентрации триглицеридов, холестерина в печени, вызывает гомоцистеинемию [23]. Диета, имеющая в своем составе свиное сало, кокосовое и оливковое масло (42\% калорийности от суточного рациона), в течение 12 нед вызывает отложение триглицеридов в печени без развития ЖГ и фиброза [24]. Использование говяжьего жира в качестве источника жира (40\% калорийности от суточного рациона) приводит к развитию ЖГ у крыс [25]. Показано, что излишек фруктозы или сахарозы в пищевом рационе также имеет свойство вызывать ЖГ у экспериментальных животных. Для развития ожирения печени обычно требуется не менее 8-24 нед (в зависимости от желаемого результата) содержания животных на диете с высокой концентрацией фруктозы [26]. Другие авторы для индукции ЖГ используют модели рациона, сочетающего большое количество жиров и углеводов, что точнее имитирует питание человека. Фруктозы в такой комбинированной высококалорийной диете может содержаться от 10 до 30\%, а жира от 20 до 40\%. Выявлено, что после 16 нед такого рациона отмечались увеличение массы печени, депонирование липидов, воспаление, фиброз, а также высокая активность печеночных ферментов в крови [27].

Таким образом, в настоящее время разработан ряд экспериментальных моделей ЖГ, способных удовлетворить требования исследователей при решении конкретных научных задач, возникающих при изучении данной проблемы. Но при этом ни одна модель ЖГ не может на 100\% быть экстраполированной на человека и каждая имеет свои особенности, что влияет на результат исследования. Все модели ЖГ не являются абсолютно стабильными и требуют тщательного отслеживания метаболических показателей печени во времени. Выбор оптимальной модели является одним из важных моментов в изучении ЖГ.

Разработанный и апробированный нами в условиях эксперимента способ моделирования ЖГ, основанный на использовании рациона питания с повышенным содержанием жиров и легкоусвояемых углеводов, позволяет, с одной стороны, с высокой эффективностью воспроизводить жировое перерождение печени, а с другой - по своим основным этиологическим и патогенетическим характеристикам максимально соответствует данной патологии, развивающейся у людей разного возраста при высококалорийном питании. Важным преимуществом способа является то, что для повышения калорийности рациона используются только натуральные продукты питания, а также природные пищевые аттрактанты, обеспечивающие высокую степень потребления корма животными. Результаты наших исследований свидетельствуют о том, что молодые крысы наиболее подвержены неблагоприятному воздействию ВР питания и риску развития ЖГ. Это позволяет рекомендовать данный способ моделирования ЖГ к использованию в экспериментальной практике при изучении возрастных закономерностей развития данной патологии, особенно у лиц молодого возраста и детей, а также разработке новых методов профилактики и коррекции в клинической практике.
Ограничения исследования

К факторам, способным существенным образом повлиять на результаты в нашем исследовании, можно отнести: точность дозировки пищевых компонентов, физиологическое состояние животных во время эксперимента.

Направления дальнейших исследований

В дальнейшем мы планируем исследовать роль продуктов метаболизма аминокислоты триптофана в процессах коррекции ЖГ.

\section{ЗАКЛЮЧЕНИЕ}

Предложенная нами модель ЖГ на основе комбинированного (жироуглеводного) высококалорийного рациона у всех лабораторных крыс приводит к развитию выраженных морфологических, биохимических и биофизических признаков данной патологии. Наибольшую степень выраженности основные патогномоничные признаки ЖГ достигают у молодых животных. Существенным преимуществом разработанной модели является простота ее реализации при полном исключении летальности животных; высокая степень соответствия по своим основным этиологическим и патогенетическим характеристикам ЖГ, развивающегося у человека при сверхкалорийном питании; относительно низкая стоимость исходных продуктов рациона (по сравнению с готовыми специальными кормами для животных); доступность всех составных компонентов предлагаемого нами экспериментального рациона. Животные питаются самостоятельно, дополнительного введения экспериментатором веществ перорально или иными путями не требуется, что исключает возникновение стрессовых реакций. Использованный рацион обеспечивает высокую степень поедаемости корма животными и поддержание нормального водного баланса организма. Показатель воспроизводимости ЖГ при использовании данной модели в течение 12 нед достигает 100\%.

\section{ДОПОЛНИТЕЛЬНАЯ ИНФОРМАЦИЯ}

Источники финансирования. Работа выполнена в рамках государственного задания «Институт физиологии им. А.А. Богомольца НАН Украины» (№ 0119U103965). Также эта работа частично поддержана из средств НАН Украины для поддержки развития приоритетных направлений исследований СРН (№ 0118U007344).

Конфликт интересов. Авторы декларируют отсутствие явных и потенциальных конфликтов интересов, связанных с публикацией настоящей статьи.

Участие авторов. Янко Р.В. - концепция и дизайн исследования; получение, анализ данных; написание статьи; Чака Е.Г. - получение, анализ данных; внесение в рукопись существенной (важной) правки с целью повышения научной ценности статьи; Зинченко А.С. - интерпретация результатов; внесение в рукопись существенной (важной) правки с целью повышения научной ценности статьи; Сафонов С.Л. получение, анализ данных; внесение в рукопись существенной (важной) правки с целью повышения научной ценности статьи; Левашов М.И. - концепция и дизайн исследования; написание статьи. Все авторы одобрили финальную версию статьи перед публикацией, выразили согласие нести ответственность за все аспекты работы, подразумевающую надлежащее изучение и решение вопросов, связанных с точностью или добросовестностью любой части работы. 


\section{СПИСОК ЛИТЕРАТУРЫ | REFERENCES}

1. Maurice J, Manousou P. Non-alcoholic fatty liver disease. Clin Med (Lond) 2018;18(3):245-250. doi: https://doi.org/10.7861/clinmedicine.18-3-245

2. Carr RM, Oranu A, Khungar V. Nonalcoholic fatty liver disease: pathophysiology and management. Gastroenterol Clin North Am. 2016;45(4):639-652. doi: https://doi.org/10.1016/j.gtc.2016.07.003

3. Li B, Zhang C, Zhan Y-T. Nonalcoholic Fatty Liver Disease Cirrhosis: A Review of Its Epidemiology, Risk Factors, Clinical Presentation, Diagnosis, Management, and Prognosis. Can J Gastroenterol Hepatol. 2018;2018:1-8. doi: https://doi.org/10.1155/2018/2784537

4. Tanaka N, Kimura T, Fujimori N, et al. Current status, problems, and perspectives of non-alcoholic fatty liver disease research. World J Gastroenterol. 2019;25(2):163-177. doi: https://doi.org/10.3748/wjg.v25.i2.163

5. Kim SH, Lim Y, Park JB, et al. Comparative study of fatty liver induced by methionine and choline-deficiency in C57BL/6N mice originating from three different sources. Lab Anim Res. 2017;33(2):157-164. doi: https://doi.org/10.5625/lar.2017.33.2.157

6. Cai-Yu Lian, Zhen-Zhen Zhai, Zi-Fa Li, et al. High fat diettriggered non-alcoholic fatty liver disease: A review of proposed mechanisms. Chemico-Biological Interactions. 2020;330:109-199. doi: https://doi.org/10.1016/j.cbi.2020.109199

7. Massart J, Begriche K, Moreau C, et al. Role of nonalcoholic fatty liver disease as risk factor for drug-induced hepatotoxicity. J Clin Trans/ Res. 2017;3(1):212-232. doi: https://doi.org/10.18053/jctres.03.2017S1.006

8. Wahlang B, Beier L, Clair HB, et al. Toxicant-associated steatohepatitis. Toxicol Pathol. 2013:41(2):343-360. doi: https://doi.org/10.1177/0192623312468517

9. Лещенко Д.В., Костюк Н.В., Белякова М.Б., и др. Диетически индуцированные животные модели метаболического синдрома (обзор литературы) // Верхневолжский медицинский журнал. 2015. - T. 14. - №2. - C. 34-39. [Leshchenko DV, Kostyuk NV, Belyakova MB, et al. Diyeticheski indutsirovannyye zhivotnyye modeli metabolicheskogo sindroma (OBZOR LITERATURY). Verkhnevolzhskiy meditsinskiy zhurnal. 2015;14(2):34-39. (in Russ.)]

10. Rudzki Z, Szczudrawa J, Stachura J. Morphometry of normal, regenerating and cancerous hepatocytes. Folia Histochem Cytobiol. 1999:27(3):141-148

11. Янко Р.В., Чака Е.Г., Литовка И.Г., Левашов М.И. Морфологические изменения печени крыс разного возраста после введения хлорида магния // Журнал Белорусского государственного университета. Биология. - 2019. №3. - C. 40-48 [Yanko RV, Chaka EG, Litovka IG, Levashov MI. Morfologicheskiye izmeneniya pecheni krys raznogo vozrasta posle vvedeniya khlorida magniya. Zhurnal Belorusskogo gosudarstvennogo universiteta. Biologiya. 2019;3:40-48. (in Russ.)] doi: https://doi.org/10.33581/2521-1722-2019-3-40-48

12. Данилов Р.К. Руководство по гистологии. Том II. - СанктПетербург: СпецЛит; 2011. [Danilov RK. Rukovodstvo po gistologii. Tom II . St. Petersburg: SpecLith; 2011. (in Russ.)].

13. Николаев Д.В., Смирнов А.В., Бобринская И.Г., Руднев С.Г. Биоимпедансный анализ состава тела человека. - М.: Наука; 2009. [Nikolayev DV, Smirnov AV, Bobrinskaya IG, Rudnev SG. Bioimpedansnyy analiz sostava tela cheloveka. Moscow: Nauka, 2009. (in Russ.)].

14. Kneeman JM, Misdraji J, Corey KE. Secondary causes of nonalcoholic fatty liver disease. Therap Adv Gastroenterol. 2012;5(3):199-207. doi: https://doi.org/10.1177/1756283X11430859
15. Crescenzo R, Bianco F, Coppola P, et al. Fructose supplementation worsens the deleterious effects of short-term high-fat feeding on hepatic steatosis and lipid metabolism in adult rats. Exp Physiol. 2014;99(9):1203-1213. doi: https://doi.org/10.1113/expphysiol.2014.079632

16. DiStefano JK. Fructose-mediated effects on gene expression and epigenetic mechanisms associated with NAFLD pathogenesis. Cell Mol Life Sci. 2020;77(11):2079-2090. doi: https://doi.org/10.1007/s00018-019-03390-0

17. Романова Л.П., Малышев И.И. Роль двуядерных гепатоцитов в регенерации печени после механической травмы в раннем онтогенезе у крыс // Вестник Чувашского университета. 2011. - №3. - C. 398-402. [Romanova LP, Malyshev II. Rol' dvuyadernykh gepatotsito $v \vee$ regeneratsii pecheni posle mekhanicheskoy travmy $\vee$ rannem ontogeneze u krys. Vestnik Chuvashskogo universiteta. 2011; 3:398-402. (In Russ.)]

18. Boisvert F, van Koningsbruggen S, Navascués J, Lamond Al. The multifunctional nucleolus. Mol Cell Biol. 2007;8(7):574-585. doi: https://doi.org/10.1038/nrm2184

19. Luedde T, Kaplowitz N, Schwabe RF. Cell death and cell death responses in liver disease: mechanisms and clinical relevance. Gastroenterology. 2014;147(4):765-783. doi: https://doi.org/10.1053/j.gastro.2014.07.018

20. Hadizadeh F, Faghihimani E, Adibi P. Nonalcoholic fatty liver disease: Diagnostic biomarkers. World J Gastrointest Pathophysiol. 2017:8(2):11-26. doi: https://doi.org/10.4291/wjgp.v8.i2.11

21. Ohmine $Y$, Morimoto $T$, Kinouchi $Y$, et al. Basic study of new diagnostic modality according to non-invasive measurement of the electrical conductivity of tissues. J Med Investig. 2004;51(3-4):218-225. doi: https://doi.org/10.2152/jmi.51.218

22. Kirpich IA, Gobejishvili LN, Bon Homme M, et al. Integrated hepatic transcriptome and proteome analysis of mice with high-fat diet-induced nonalcoholic fatty liver disease. J Nutr Biochem. 2011;22(1):38-45 doi: https://doi.org/10.1016/j.jnutbio.2009.11.009

23. Bravo E, Palleschi S, Aspichueta P, et al. High fat dietinduced non alcoholic fatty liver disease in rats is associated with hyperhomocysteinemia caused by down regulation of the transsulphuration pathway. Lipids Health Dis. 2011;10:60. doi: https://doi.org/10.1186/1476-511X-10-60

24. Buettner R, Parhofer KG, Woenckhaus M, et al. Defining high-fat-diet rat models: metabolic and molecular effects of different fat types. J Mol Endocrinol. 2006;36(3):485-501. doi: https://doi.org/10.1677/jme.1.01909

25. Hsu C-L, Wu C-H, Huang S-L, Yen G-C. Phenolic Compounds Rutin and o -Coumaric Acid Ameliorate Obesity Induced by High-Fat Diet in Rats. J Agric Food Chem. 2009;57(2):425-431. doi: https://doi.org/10.1021/jf802715t

26. Jensen T, Abdelmalek MF, Sullivan S, et al. Fructose and sugar: A major mediator of non-alcoholic fatty liver disease. Journal of hepatology. 2018;68(5):1063-1075 doi: https://doi.org/10.1016/j.jhep.2018.01.019

27. Panchal SK, Poudyal H, lyer A, et al. High-carbohydrate highfat diet-induced metabolic syndrome and cardiovascular remodeling in rats. J Cardiovasc Pharmacol. 2011;57(1):51-64 doi: https://doi.org/10.1097/FJC.0b013e3181feb90a

\section{ИНФОРМАЦИЯ ОБ АВТОРАХ [AUTHORS INFO]:}

*Янко Роман Васильевич, к.б.н. [Roman V. Yanko, PhD in biology]; адрес: 01024, Украина, Киев, ул. Богомольца, д. 4 [address: 4 Bogomolets Street, 01024 Kiev, Ukraine]; ORCID: https://orcid.org/0000-0002-0397-7517; eLibrary SPIN: 7701-2184; e-mail: biolag@ukr.net

Чака Елена Георгиевна, к.б.н. [Elena G. Chaka, PhD in biology]; ORCID: https://orcid.org/0000-0001-7425-2751; eLibrary SPIN: 9509-2563; e-mail: lenchaka@ukr.net

Зинченко Анастасия Сергеевна, аспирант [Anastasia S. Zinchenko, postgraduate student];

ORCID: https://orcid.org/0000-0003-4824-7689; e-mail: anastazi.de.resto@gmail.com

Сафонов Сергей Леонидович [Sergey L. Safonov]; ORCID: https://orcid.org/0000-0002-4785-0315;

e-mail: sersaffiz@gmail.com

Левашов Михаил Иванович, д.м.H. [Mikhail I. Levashov, MD, PhD]; ORCID: https://orcid.org/0000-0003-1354-2047; eLibrary SPIN: 7467-9830; e-mail: levashov@biph.kiev.ua 
*Автор, ответственный за переписку / Corresponding author.

\section{ЦИТИРОВАТЬ:}

Янко Р.В., Чака Е.Г., Зинченко А.С., Сафонов С.Л., Левашов М.И. Особенности моделирования жирового гепатоза у крыс разного возраста на основе высококалорийного рациона // Ожирение и метаболизм. - 2021. — Т. 18. — №4. C. 387-397. doi: https://doi.org/10.14341/omet12789

\section{TO CITE THIS ARTICLE:}

Yanko RV, Chaka EG, Zinchenko AS, Safonov SL, Levashov ML. Features of modeling fatty liver disease in rats of different ages based on a high-calorie diet. Obesity and metabolism. 2020;18(4):387-397. doi: https://doi.org/10.14341/omet12789 